\title{
ENVIRONMENTAL ASSESSMENT FOR PROPOSED ENERGY CONSERVATION STANDARDS FOR REFRIGERATORS, REFRIGERATOR-FREEZERS, AND FREEZERS
}

JANUARY 1996

\author{
RECEIVED \\ OCT 271997 \\ OSTI
}

\author{
U.S. Department of Energy \\ Assistant Secretary \\ Energy Efficiency \& Renewable Energy \\ Office of Codes and Standards \\ Washington, DC 20585
}

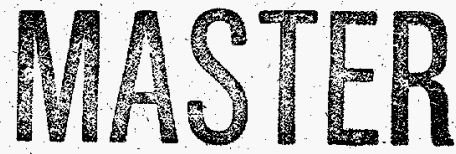




\section{DISCLAMIER}

Portions of this document may be illegible in electronic image products. Images are produced from the best available original documert. 


\section{ENVIRONMENTAL ASSESSMENT FOR THE PROPOSED ENERGY CONSERVATION STANDARD FOR REFRIGERATORS, REFRIGERATOR- FREEZERS, AND FREEZERS}

\section{INTRODUCTION AND NEED FOR PROPOSED ACTION}

This Environmental Assessment (EA) on the candidate energy conservation standards for. refrigerators, refrigerator-freezers, and freezers was prepared pursuant to the National Environmental Policy Act of 1969 (NEPA), regulations of the Council on Environmental Quality, Title 40, Code of Federal Regulations, Parts 1500 through 1508. The proposed energy conservation standard (Level 1) and the alternative standards are being reviewed in an energyefficiency standards rulemaking that the Department has undertaken pursuant to the Energy Policy and Conservation Act, as amended by the National Energy Conservation Policy Act and the National Appliance Energy Conservation Act [1]. See Notice of Proposed Rulemaking Regarding Energy Conservation Standards for Refrigerators, Refrigerator-Freezers, and Freezers. 60 FR 37388 (July 20,1995). A draft EA was prepared and made available to the public at the time of publication of the proposed rule. The Department received no comments on the draft EA.

The EA presents the associated environmental impacts from four energy conservation standards for this type of household appliance. For purposes of this EA, each standard is an alternative action and is compared to what is expected to happen if no new standards for this type of product were finalized, i.e., the "no action" alternative. Of the four energy conservation standard levels considered, standard level 4 has the highest level of energy efficiency and the largest environmental impact. The proposed action implementing Standard Level 1 would have the least environmental impacts, through emission reductions, of the four alternatives.

The description of the standards below results from the appliance energy-efficiency analyses conducted for the rulemaking. The presentation of environmental impacts for each of the alternatives appears at Section 3 of the EA.

The proposed Standard Level 1. This standard level is projected to save 7.0 quadrillion British thermal units (quads), the equivalent of 6.7 exajoules (EJ) of energy for refrigerators and refrigerator-freezers, and 0.5 quads ( $0.4 \mathrm{EJ})$ for freezers. The technologies that are necessary to meet this standard level are presently available. The consumer payback (i.e. repayment of purchase price increase) of this standard level is 3.7 years for the largest class and no more than 9.2 years for any class.

This standard is at or near the lowest life-cycle cost for all classes and is expected to result in a reduction in life-cycle cost of approximately $\$ 143$ or 11.5 percent for the largest class. The standard is expected to have essentially no impact on the prototypical manufacturer's return on equity of 7.3 percent. 
Standard Level 2. This standard level is projected to save 7.8 quads (8.2 EJ) of energy for refrigerators and refrigerator-freezers, and 1.3 quads (1.4 EJ) for freezers. However, this level requires an increase in insulation with a corresponding increase in wall thickness. Furthermore, the payback may be as long as 19.0 years, the expected life of the product. The Notice of Proposed Rulemaking that the initial burden on the manufacturers would be unacceptably high for their standard level: short-run return on equity for both refrigerators and freezers decreases from 7.3 percent to 6.2 percent, a reduction of 16 percent.

Standard Level 3. This standard level is projected to save 8.6 quads ( $9.1 \mathrm{EJ}$ ) of energy for refrigerators and refrigerator-freezers and 1.7 quads $(1.8 \mathrm{EJ})$ for freezers. While this level does not use vacuum panels, for most of the classes about 40 percent of the energy savings are obtained by increasing the insulation values. The Notice of Proposed Rulemaking noted that there is general agreement that an increase in the wall thickness is not acceptable for many of the larger models in each class. This level has payback periods as high as 25.5 years (much longer than the product life) and reduces refrigerator manufacturer short-run return on equity from 7.3 percent to 5.8 percent, a reduction of 20 percent. For freezer manufacturers, short-run return on equity drops from 7.3 percent to 4.7 percent, a reduction of more than 35 percent.

Standard Level 4. Standard level 4, the maximum technologically feasible (Max Tech) Tevel of efficiency, would save the most energy: 10.0 quads (10.55 EJ) for refrigerators (including refrigerator-freezers) and 2.0 quads (2.11 EJ) for freezers between 1998 and 2030. In order to meet this standard, the Department assumes that all refrigerator products would incorporate vacuum panel insulation. The use of vacuum panel insulation accounts for 30 percent of total energy savings, with increased wall thickness as the only alternative. The Notice of Proposed Rulemaking that reported that vacuum panel technology has progressed, but it is not ready to be applied as a reliable design option in the production of a 1998 compliant product. There are concerns about manufacturability, availability, reliability, and performance. Vacuum panels are 6 to 10 times heavier than foam. The increase in door weight may cause the appliance to tip over when the door is opened. Also, current production capability for vacuum panels is far too small for the projected demand. A 1 -inch increase in wall and door thickness (a 2-inch increase in the side-to-side dimension) is not a viable option. Many products are already constrained by the need to fit into existing spaces and through doors and passage-ways. Decreasing interior volume would sacrifice product utility.

In the evaluation of the proposed action and the alternatives, the primary environmental concern that is addressed is atmospheric emissions from fossil-fueled electricity generation. Residential refrigeration is fueled almost entirely by electricity, and this standard is not expected to affect propane residential refrigeration, which is widely used only where grid power is unavailable. The proposed design options for this appliance type would result in decreased electricity use and, therefore, a reduction of power plant emissions. The greatest decreases in air pollution would be for sulfur oxides, listed in equivalent weight of sulfur dioxide, or $\mathrm{SO}_{2}$. Reductions of nitrogen oxides and carbon dioxide would also occur and are listed by weight of $\mathrm{NO}_{2}$ and $\mathrm{CO}_{2}$, respectively. $\mathrm{CO}_{2}$ emissions from fossil-fuel burning is considered an 
environmental hazard because it contributes to the "greenhouse effect" by trapping heat energy from the earth that is emitted as infrared radiation. The greenhouse effect is expected gradually to raise the mean global temperature.

Although the quantity of raw materials used per appliance would remain relatively constant, in most scenarios increased initial cost is expected to decrease slightly the number of appliances sold, resulting in small decreases in raw materials used. The main effect of the appliance production decrease would be reduced $\mathrm{SO}_{2}$ emitted in steel production. That reduction would be small, however, in comparison to the $\mathrm{SO}_{2}$ decreases from fuel burning avoided at power plants. The contribution from steel production is not included in the estimates for net $\mathrm{SO}_{2}$ decreases resulting from design changes in these products.

The effects on particulate emissions related to the proposed standard-induced decrease in electricity generation would be minor compared to effects on decreases in $\mathrm{SO}_{2}, \mathrm{NO}_{\mathrm{x}}$, and $\mathrm{CO}_{2}$. For example, in 1984, power plants contributed only $7 \%$ of U.S. total particulate emissions as compared to contributions of $83 \%$ and $34 \%$ to total $\mathrm{SO}_{2}$ and $\mathrm{NO}_{x}$ emissions, respectively. Though the reduction in particulate emissions would be relatively small, any reduction would possibly be beneficial to improving the quality of surface water. Since the amount of particulates emitted would be decreased, it is very likely that less particulates would reach surface water.

Reductions in particulate emissions accompanied by decreases in $\mathrm{SO}_{2}$ and $\mathrm{NO}_{\mathrm{x}}$ would have other beneficial effects on the environment. The resultant improvement to air quality and the decreased potential of acid rain formation would help improve the quality of wetlands and fish and wildlife as well as aid in the preservation of historical and archaeological sites. Reductions in $\mathrm{NO}_{\mathbf{x}}$ emissions within warm urban areas is particularly beneficial because it is an urban smog precursor gas as well as an air pollutant in its own right.

\section{METHODS OF ESTIMATING ENVIRONMENTAL IMPACTS}

The greatest impacts of the proposed actign and alternative standards would be a reduction in electricity demand growth. The main environmental effects of power plants on air and water quality result from emissions of sulfur dioxide $\left(\mathrm{SO}_{2}\right)$, nitrogen oxides $\left(\mathrm{NO}_{\mathrm{x}}\right)$, and carbon dioxide $\left(\mathrm{CO}_{2}\right)$. Since the proposed standards would lessen the need for electricity generation, power plant emissions would be reduced.

\subsection{Baseline Emissions}

In the Service Report that accompanies the 1991 National Energy Strategy (NES) [2], the impact on power plant emissions as a result of Title IV of the Clean Air Act Amendments of 1990, P. L. 101-549, 104 Stat. 2399 (Nov. 15, 1990) codified as amended at 42 U. S. C. $\$ \S$ 7401-7626 (Supp. II 1990) are estimated. These estimates comprise the baseline case, and serve as the basis for comparison of emission reductions among the proposed standard and alternatives. 
In the report accompanying the $1991 \mathrm{NES}$, two possible outcomes are presented, a flexible case and a restricted case, so that the effect of different levels of permitted trading of emission allowances can be evaluated. (The report does not go beyond this explanation in defining the differences between the two cases.) As presented in the report, the results for the two cases are virtually identical. Because the two cases are so similar, only the U.S. power plant emission projections for the three effluents under the assumptions made in the flexible case are presented. Tables $1 . a$ and $1 . b$ summarize the results.

Table 1.a Projected U.S. $\mathrm{CO}_{2}, \mathrm{SO}_{2}$, and $\mathrm{NO}_{\mathbf{x}}$ Power Plant Emissions - Baseline Case (Metric Units)

\begin{tabular}{|c|c|c|c|}
\hline Year & $\begin{array}{c}\mathrm{CO}_{2} \\
\text { Million tons } \\
(\mathrm{Mt})\end{array}$ & $\begin{array}{c}\mathrm{SO}_{2} \\
\text { Million tons } \\
(\mathrm{Mt})\end{array}$ & $\begin{array}{c}\mathrm{NO}_{\mathbf{x}} \\
\text { Million tons } \\
(\mathrm{Mt})\end{array}$ \\
\hline 1995 & 2025 & 12.5 & 7.6 \\
2000 & 2274 & 8.2 & 6.1 \\
2010 & 2920 & 7.6 & 6.6 \\
2020 & 3596 & 6.1 & 6.1 \\
2030 & 4358 & 4.4 & 5.4 \\
\hline
\end{tabular}

Table 1.b Projected U.S. $\mathrm{CO}_{2}, \mathrm{SO}_{2}$, and $\mathrm{NO}_{\mathrm{I}}$ Power Plant Emissions - Baseline Case (Inch-Pound Units)

\begin{tabular}{|c|c|c|c|}
\hline Year & $\begin{array}{c}\mathrm{CO}_{2} \\
10^{6} \text { short tons }\end{array}$ & $\begin{array}{c}\mathrm{SO}_{2} \\
10^{6} \text { short tons }\end{array}$ & $\begin{array}{c}\mathrm{NO}_{\mathrm{x}} \\
10^{6} \text { short tons }\end{array}$ \\
\hline 1995 & 2233 & 13.8 & 8.4 \\
2000 & 2506 & 9.0 & 6.7 \\
2010 & 3219 & 8.4 & 7.3 \\
2020 & 3964 & 6.7 & 6.7 \\
2030 & 4804 & 4.8 & 5.9 \\
\hline
\end{tabular}

\section{1(a) Sulfur and Nitrogen Oxide Emissions}

For each of the alternatives analyzed, emissions abated from fossil fuel-burning power plants are estimated. In the analysis of the impacts of design changes to the appliances, lower sulfur emissions resulting from decreased steel production are not considered. No changes in the amount of steel used per unit are expected.

In order to reflect more fully the effects of cleaner-burning power plants in future years, 
emission rates $(\mathrm{g} / \mathrm{kWh})$ for power plant fuel-burning are calculated from projected emissions and electrical generation data. The electrical generation data is translated below into energy use (EJ) by assuming a $30 \%$ overall energy conversion efficiency. As noted above, the source of these projected emissions and electrical generation data is the Service Report that accompanied the 1991 NES (data for Tables 1.a and 1.b were extracted from the same Service Report). Tables 2.a and $2 . b$ present these data and the calculated emission rates for $\mathrm{SO}_{2}$ and $\mathrm{NO}_{\mathrm{x}}$.

Table 2.a Projected Electricity Generation, Emissions Data, and Emission Rates for $\mathrm{SO}_{2}$ and $\mathrm{NO}_{\mathbf{x}}$ at Fossil Fuel-Burning Power Plants - Metric Units

\begin{tabular}{|c|c|c|c|c|c|c|c|c|}
\hline \multirow[b]{2}{*}{ Year } & \multicolumn{3}{|c|}{$\begin{array}{c}\text { Electricity Generation } \\
\text { (TeraWattHours) } \\
\text { (TWH) }\end{array}$} & \multirow{2}{*}{$\begin{array}{c}\text { Energy Use } \\
\text { Total } \\
\text { Exajoules } \\
\end{array}$} & \multicolumn{2}{|c|}{$\begin{array}{c}\text { Emissions } \\
\text { (Million Tons) } \\
\text { (MT) }\end{array}$} & \multicolumn{2}{|c|}{$\begin{array}{l}\text { Emissions Rates (generation) } \\
\text { gram/kiloWatthours (g/kWh) }\end{array}$} \\
\hline & Coal & Oil & Gas & & $\mathrm{SO}_{2}$ & Nox & $\mathrm{SO}_{2}$ & $\mathrm{NO}_{\mathrm{x}}$ \\
\hline 1995 & 1602.2 & 193.7 & 442.0 & 27 & 12.5 & 7.6 & 5.6 & 3.4 \\
\hline 2000 & 1814.0 & 179.8 & 605.0 & 31 & 8.2 & 6.1 & 3.1 & 2.3 \\
\hline 2010 & 2660.6 & 149.9 & 482.5 & 40 & 7.6 & 6.6 & 2.3 & 2.0 \\
\hline 2020 & 3727.8 & 67.2 & 292.3 & 49 & 6.1 & 6.1 & 1.5 & 1.5 \\
\hline 2030 & 4837.3 & 29.0 & 179.2 & 61 & 4.4 & 5.4 & 0.9 & 1.1 \\
\hline
\end{tabular}

Table 2.b Projected Electricity Generation, Emissions Data, and Emission Rates for $\mathrm{SO}_{2}$ and $\mathrm{NO}_{\mathrm{x}}$ at Fossil Fuel-Burning Power Plants - Inch-Pound Units

\begin{tabular}{|c|c|c|c|c|c|c|c|c|}
\hline \multirow[b]{2}{*}{ Year } & \multicolumn{3}{|c|}{$\begin{array}{c}\text { Electricity Generation } \\
\text { (kiloWatthours) } \\
(\mathrm{kWh})\end{array}$} & \multirow{2}{*}{$\begin{array}{c}\text { Energy Use } \\
\text { Total } \\
\text { quadrillion } \\
\text { British tons } \\
\text { (Quads) }\end{array}$} & \multicolumn{2}{|c|}{ Emissions } & \multicolumn{2}{|c|}{ Emissions Rates (primary) } \\
\hline & $\begin{array}{c}\text { Coal } \\
10^{9}\end{array}$ & $\begin{array}{l}\text { Oil } \\
10^{9}\end{array}$ & $\begin{array}{l}\text { Gas } \\
10^{9}\end{array}$ & & $\begin{array}{c}\mathrm{SO}_{2} \\
10^{6} \\
\text { short tons }\end{array}$ & $\begin{array}{c}\mathrm{NO}_{\mathrm{x}} \\
10^{6} \\
\text { short tons }\end{array}$ & $\begin{array}{c}\mathrm{SO}_{2} \\
10^{3} \\
\text { tons/Quad }\end{array}$ & $\begin{array}{r}\mathrm{NO}_{\mathrm{x}} \\
10^{3} \\
\text { tons/Quad }\end{array}$ \\
\hline 1995 & 1602.2 & 193.7 & 442.0 & 25.74 & 13.8 & 8.4 & 552.5 & 336.3 \\
\hline 2000 & 1814.0 & 179.8 & 605.0 & 29.89 & 9.0 & 6.7 & 310.3 & 231.0 \\
\hline 2010 & 2660.6 & 149.9 & 482.5 & 37.88 & 8.4 & 7.3 & 228.6 & 198.6 \\
\hline 2020 & 3727.8 & 67.2 & 292.3 & 47.01 & 6.7 & 6.7 & 146.9 & 146.9 \\
\hline 2030 & 4837.3 & 29.0 & 179.2 & 58.03 & 4.8 & 5.9 & 85.2 & 104.8 \\
\hline
\end{tabular}

The calculated emissions rate data listed in Tables 2.a and 2.b represent the average $\mathrm{SO}_{2}$ and $\mathrm{NO}_{\mathrm{x}}$ emissions rates for all fossil fuel-burning power plants in the United States. Emissions 
rates were not calculated for each fuel-burning source as the emissions data supplied by the Service Report were not disaggregated according to power plant type (i.e., coal, oil, gas). To obtain emission rate values, the amount of emissions was divided by the total energy use of fossil fuel-burning power plants. The total energy use by fossil fuel-burning power plants was calculated from the electrical generation data supplied by the report accompanying the $1991 \mathrm{NES}$. The electrical generation data was disaggregated by fuel source. To obtain the total energy use (input), the electrical generation data from each fossil fuel source was summed and then divided by the assumed efficiency of fossil fuel-burning power plants (30\%), which includes transmission and distribution losses. This fossil fuel-burning power plant efficiency is consistent with that used by the LBL Residential Energy Model (LBL-REM).

The amount of $\mathrm{SO}_{2}$ and $\mathrm{NO}_{x}$ emissions abated for any particular year is determined by multiplying the estimates of energy saved through reduced electricity generation in that year by the emission rate for that particular year. For years not covered in the Service Report, linear interpolation was used to derive emission rates and, in turn, the corresponding abated emissions.

\section{1(b) Carbon Dioxide Emissions}

Emission rates for $\mathrm{CO}_{2}$ were derived in the same manner as those derived for $\mathrm{SO}_{2}$ and $\mathrm{NO}_{\mathrm{x}}$. Table 3.a and 3.b present the $\mathrm{CO}_{2}$ emission rate data as derived from the electrical generation data and emissions data supplied by the 1991 NES Service Report.

Table 3.a Projected Electricity Generation Data, Emissions Data, and Emissions Rates for $\mathrm{CO}_{2}$ at Fossil Fuel-Burning Power Plants - Metric Units

\begin{tabular}{|c|c|c|c|c|c|c|}
\hline \multirow[b]{2}{*}{ Year } & \multicolumn{3}{|c|}{ Electricity Generation } & \multirow[b]{2}{*}{$\begin{array}{c}\text { Energy Use } \\
\text { Total } \\
\text { Exajoules } \\
\text { (EJ) }\end{array}$} & \multirow[b]{2}{*}{$\begin{array}{c}\text { Emission } \\
\mathrm{CO}_{2} \\
\text { Million Tons } \\
\text { (MT) } \\
\end{array}$} & \multirow[b]{2}{*}{$\begin{array}{c}\text { Emission Rate } \mathrm{CO}_{2} \\
\text { grams/kiloWatthours } \\
(\mathrm{g} / \mathrm{kWh})\end{array}$} \\
\hline & $\begin{array}{c}\text { Coal } \\
\text { TeraWattH } \\
\text { ours } \\
\text { (TWH) }\end{array}$ & $\begin{array}{c}\text { Oil } \\
\text { TeraWattH } \\
\text { ours } \\
\text { (TWH) }\end{array}$ & $\begin{array}{c}\text { Gas } \\
\text { TeraWatt } \\
\text { Hours } \\
\text { (TWH) }\end{array}$ & & & \\
\hline 1995 & 1602.2 & 193.7 & 442.0 & 27 & 2025 & 905 \\
\hline 2000 & 1814.0 & 179.8 & 6050 & 31 & 2274 & $875^{\prime}$ \\
\hline 2010 & 2660.6 & 149.9 & 482.5 & 40 & 2920 & 887 \\
\hline 2020 & 3727.8 & 67.2 & 292.3 & 49 & 3596 & 880 \\
\hline 2030 & 4837.3 & 29.0 & 179.2 & 61 & 4358 & 864 \\
\hline
\end{tabular}


Table 3.b Projected Electricity Generation Data, Emissions Data, and Emissions Rates for $\mathrm{CO}_{2}$ at Fossil Fuel-Burning Power Plants - Inch-Pound Units

\begin{tabular}{|c|c|c|c|c|c|c|}
\hline \multirow[b]{2}{*}{ Year } & \multicolumn{3}{|c|}{ Electricity Generation } & \multirow[b]{2}{*}{$\begin{array}{c}\text { Energy Use Total } \\
\text { quadrillion } \\
\text { British tons } \\
\text { (Quads) }\end{array}$} & \multirow[b]{2}{*}{$\begin{array}{c}\text { Emission } \mathrm{CO}_{2} \\
10^{6} \\
\text { short tons } \\
\end{array}$} & \multirow[b]{2}{*}{$\begin{array}{c}\text { Emission Rate } \mathrm{CO}_{2} \\
10^{\circ} \\
\text { tons/Quad } \\
\end{array}$} \\
\hline & $\begin{array}{c}\text { Coal } \\
10^{9} \\
\text { kiloWatt } \\
\text { hours } \\
\text { (KWh) }\end{array}$ & $\begin{array}{c}\text { Oil } \\
10^{\circ} \\
\text { kiloWatt } \\
\text { hours } \\
(\mathrm{KWh})\end{array}$ & $\begin{array}{c}\text { Gas } \\
10^{\circ} \\
\text { kiloWatt } \\
\text { hours } \\
(\mathrm{KWh})\end{array}$ & & & \\
\hline 1995 & 1602.2 & 193.7 & $442.0^{\prime}$ & 25.74 & 2232.5 & 89.39 \\
\hline 2000 & 1814.0 & 179.8 & 605.0 & 29.89 & 2506.2 & 86.41 \\
\hline 2010 & 2660.6 & 149.9 & 482.5 & 37.88 & 3219.3 & 87.60 \\
\hline 2020 & 3727.8 & 67.2 & 292.3 & 47.01 & 3964.2 & 86.90 \\
\hline 2030 & 4837.3 & 29.0 & 179.2 & 58.03 & 4804.4 & 85.32 \\
\hline
\end{tabular}

As with the $\mathrm{SO}_{2}$ and $\mathrm{NO}_{\mathrm{x}}$ emissions, the amount of $\mathrm{CO}_{2}$ emissions abated for any particular year is determined by multiplying the estimates of energy saved through reduced electricity generation by the emission rate for that particular year. For years not covered in the Service Report, linear interpolation was used to derive emission rates and, in turn, the corresponding abated emissions.

\section{ENVIRONMENTAL IMPACTS}

The following results in Table 4-7 indicate projected changes that could be brought about in the amounts of emitted $\mathrm{CO}_{2}, \mathrm{SO}_{2}$, and $\mathrm{NO}_{\mathrm{x}}$ by imposing efficiency standards for appliances at each of the four standard levels considered in this analysis. A table is presented for each of the standard levels. Each table details the changes that would occur to each of the three emissions (i.e., $\mathrm{CO}_{2}, \mathrm{SO}_{2}$, and $\mathrm{NO}_{\mathrm{x}}$ ) through the implementation of a particular standard level for this type of appliance. Each table shows, for a specific year between 1998, the first year in which the proposed standard would be implemented, and 2030, the amount of emission abated from power plant generation, as compared against the baseline case. Also included are the cumulative changes of each pollutant (between the years 1998 and 2030). The estimated of $\mathrm{SO}_{2}, \mathrm{NO}_{\mathrm{x}}$, and $\mathrm{CO}_{2}$ in Tables 4-7 are also exposed as a percentage of U.S. power plant emissions for the year under consideration.

\subsection{Sulfür and Nitrogen Oxide Emissions}

Sulfur dioxide emissions would be decreased by a cumulative total of up to $1720 \mathrm{kt}$ ( 1896 thousand short tons) between 1998 and 2030 at energy conservation standard level 4, the most stringent standard level. In the year 2000, Standard Level 4 decreases in $\mathrm{SO}_{2}$ would represent about $0.19 \%$ of the $\mathrm{SO}_{2}$ emissions estimated to come from power plants in that year. In the year 2030 , decreases in $\mathrm{SO}_{2}$ emissions will represent about $1.2 \%$ of the $\mathrm{SO}_{2}$ emissions estimated to 
come from power plants in that year. As discussed earlier, the possible reductions of $\mathrm{SO}_{2}$ emissions caused by standards will reduce the utility's need to purchase allowances or permit it to save them for future use, or sell them. To the extent saved allowances are used for future emissions, the standards' net effect on those $\mathrm{SO}_{2}$ emissions would be only a reduction in the demand for emissions allowances.

Standard Level 4 design changes to residential refrigeration would result in an estimated decrease in $\mathrm{NO}_{x}$ emissions of $1635 \mathrm{kt}$ (1802 thousand short tons) between 1998 and $2030 . \mathrm{NO}_{\mathrm{x}}$ decreases would represent $0.19 \%$ and $1.2 \%$ of the $\mathrm{NO}_{x}$ emissions estimated to come from power plants in the years 2000 and 2030 , respectively.

\subsection{Carbon Dioxide Emissions}

The cumulative reduction in $\mathrm{CO}_{2}$ emissions from Standard Level 4 design changes is 914 Mt (1007 million short tons of $\mathrm{CO}_{2}$ ). 
Table 4. Projected Reduction of Pollutants for Refrigerators, Refrigerator-Freezers, and Freezers, Standard Level One

$\mathrm{SO}_{2}$

\begin{tabular}{|c|c|c|c|c|c|}
\hline Year & $\begin{array}{l}\mathrm{Al} \\
\mathrm{kt} \\
\end{array}$ & $\begin{array}{l}\text { from Power Plant } \\
\text { Generation } \\
\text { (10 } 0^{3} \text { of short tons) }\end{array}$ & $\mathrm{kt}$ & $\begin{array}{l}\text { otal Emissions } \\
\left(10^{3} \text { of short tons) }\right.\end{array}$ & $\begin{array}{l}\% \text { U.S. } \mathrm{SO}_{2} \text { Power } \\
\text { Plant Emissions }\end{array}$ \\
\hline 1998 & 4.9 & 5.4 & 12362 & 13623 & -0.04 \\
\hline 2000 & 11.2 & 12.3 & 9853 & 10858 & -0.11 \\
\hline 2005 & 26.8 & 29.5 & 8867 & 9772 & -0.30 \\
\hline 2010 & 38.8 & 42.8 & 7956 & 8767 & -0.49 \\
\hline 2015 & .42 .3 & 46.6 & 6546 & 7214 & -0.65 \\
\hline 2020 & 38.5 & 42.5 & 5489 & 6048 & -0.70 \\
\hline 2025 & 31.1 & 34.3 & 4412 & 4862 & -0.70 \\
\hline 2030 & 24.5 & 27.0 & 3488 & 3844 & -0.70 \\
\hline
\end{tabular}

Cumulative $\mathrm{SO}_{2}$ reduction, $1998-2030=1017 \mathrm{kt}$ (1120 thousand short tons)

\begin{tabular}{|c|c|c|c|c|c|}
\hline Year & & $\begin{array}{l}\text { from Power Plant } \\
\text { Generation } \\
\left(10^{3} \text { of short tons) }\right.\end{array}$ & kt & $\begin{array}{l}\text { otal Emissions } \\
\left(10^{3} \text { of short tons) }\right.\end{array}$ & $\begin{array}{l}\% \text { U.S. } \mathrm{NO}_{\mathrm{x}} \text { Power } \\
\text { Plant Emissions }\end{array}$ \\
\hline 1998 & 3.3 & 3.7 & 8356 & $\therefore 9208$ & -0.04 \\
\hline 2000 & 8.3 & 9.2 & 7335 & 8083 & -0.11 \\
\hline 2005 & 21.6 & 23.8 & 7136 & 7864 & -0.30 \\
\hline 2010 & 33.7 & 37.2 & 6914 & 7619 & -0.49 \\
\hline 2015 & 39.2 & 43.2 & 6070 & 6689 & -0.65 \\
\hline 2020 & 38.5 & 42.5 & 5489 & 6048 & -0.70 \\
\hline 2025 & 34.1 & 37.6 & 4836 & 5330 & -0.70 \\
\hline 2030 & 30.2 & 33.3 & 4289 & 4726 & -0.70 \\
\hline
\end{tabular}

Cumulative $\mathrm{NO}_{\mathrm{x}}$ reduction, $1998-2030=966 \mathrm{kt}$ (1065 thousand short tons)

\begin{tabular}{|c|c|c|c|c|c|}
\hline \multirow[t]{2}{*}{ Year } & \multicolumn{2}{|c|}{$\begin{array}{l}\text { Abated from Power Plant } \\
\text { Generation }\end{array}$} & \multicolumn{2}{|c|}{ Total Emissions } & \multirow[t]{2}{*}{$\begin{array}{l}\% \text { U.S. CO } \mathrm{CO}_{2} \text { Power } \\
\text { Plant Emissions }\end{array}$} \\
\hline & Mt & ( $10^{9}$ short tons) & $\mathrm{kt}$ & (10 short tons) & \\
\hline 1998 & 1.1 & 1.2 & 2714 & 2990 & -0.04 \\
\hline 2000 & 3.1 & 3.4 & 2744 & 3024 & -0.11 \\
\hline 2005 & 8.8 & 9.7 & 2918 & 3216 & -0.30 \\
\hline 2010 & 14.9 & 16.4 & 3049 & 3360 & -0.49 \\
\hline 2015 & 20.1 & 22.2 & 3114 & 3432 & $-0,65$ \\
\hline 2020 . & 22.8 & 25.1 & 3248 & 3579 & -0.70 \\
\hline 2025 & 23.7 & 26.1 & 3365 & 3708 & -0.70 \\
\hline 2030 & 24.6 & 27.1 & 3491 & 3848 & -0.70 \\
\hline
\end{tabular}

Cumulative $\mathrm{CO}_{2}$ reduction, $1998-2030=540 \mathrm{Mt}$ ( 595 million short tons) 
Table 5. Projected Reduction of Pollutants for Refrigerators, RefrigeratorFreezers, and Freezers, Standard Level Two

SO,

\begin{tabular}{|c|c|c|c|c|c|}
\hline Year & & $\begin{array}{l}\text { from Power Plant } \\
\text { Generation } \\
\left(10^{3} \text { of short tons) }\right.\end{array}$ & kt & $\begin{array}{l}\text { al Emissions } \\
\text { (10 } 10^{3} \text { of short tons) }\end{array}$ & $\begin{array}{l}\% \text { U.S. SO }{ }_{2} \text { Power } \\
\text { Plant Emissions }\end{array}$ \\
\hline 1998 & 6.0 & 6.6 & 12362 & 13623 & -0.05 \\
\hline 2000 & 14.5 & 16.0 & 9853 & 10858 & -0.15 \\
\hline 2005 & 34.0 & 37.5 & $8867^{\circ}$ & 9772 & -0.38 \\
\hline 2010 & 49.3 & 54.3 & 7956 & 8767 & -0.62 \\
\hline 2015 & 53.7 & 59.2 & 6546 & 7214 & -0.82 \\
\hline 2020 & 49.0 & 54.0 & 5489 & 6048 & -0.89 \\
\hline 2025 & 39.5 & 43.6 & 4412 & 4862 & -0.90 \\
\hline 2030 & 31.2 & 34.3 & 3488 & 3844 & -0.89 \\
\hline
\end{tabular}

Cumulative $\mathrm{SO}_{2}$ reduction, $1998-2030=1292 \mathrm{kt}$ (1424 thousand short tons)

\begin{tabular}{|c|c|c|c|c|c|}
\hline \multirow[t]{2}{*}{ Year } & \multicolumn{2}{|c|}{$\begin{array}{c}\text { Abated from Power Plant } \\
\text { Generation }\end{array}$} & \multicolumn{2}{|c|}{ Total Emissions } & \multirow[t]{2}{*}{$\begin{array}{l}\text { \% U.S. NO }{ }_{x} \text { Power } \\
\text { Plant Emissions }\end{array}$} \\
\hline & kt & ( $10^{3}$ of short tons) & kt & ( $10^{3}$ of short tons) & \\
\hline 1998 & 4.0 & 4.4 & 8356 & 9208 & -0.05 \\
\hline 2000 & 10.8 & 11.9 & 7335 & 8083 & -0.15 \\
\hline 2005 & 27.4 & 30.2 & 7136 & 7864 & -0.38 \\
\hline 2010 & 42.8 & 47.2 & 6914 & 7619 & -0.62 \\
\hline 2015 & 49.8 & 54.9 & 6070 & 6689 & -0.82 \\
\hline 2020 & 49.0 & $54.0^{\circ}$ & 5489 & 6048 & -0.89 \\
\hline 2025 & 43.3 & 47.8 & 4836 & 5330 & -0.90 \\
\hline 2030 & 38.4 & 42.3 & 4289 & 4726 & -0.89 \\
\hline
\end{tabular}

Cumulative $\mathrm{NO}_{\mathrm{x}}$ reduction, $1998-2030=1228 \mathrm{kt}$ ( 1353 thousand short tons)

\begin{tabular}{|c|c|c|c|c|c|}
\hline Year & $\begin{array}{c}\text { Abate } \\
\mathrm{Mt}\end{array}$ & $\begin{array}{l}\text { fom Power Plant } \\
\text { eneration } \\
\left(10^{9} \text { short tons }\right)\end{array}$ & $\mathrm{kt}$ & $\begin{array}{l}\text { otal Emissions } \\
\text { (10 of short tons) }\end{array}$ & $\begin{array}{l}\% \text { U.S. } \mathrm{CO}_{2} \text { Power } \\
\text { Plant Emissions }\end{array}$ \\
\hline 1998. & 13 & 1.40 & 2714 & 2990 & -0.05 \\
\hline 2000 & 4.0 & 4.40 & 2744 & 3024 & -0.15 \\
\hline 2005 & 11.2 & 12.30 & 2918 & 3216 & -0.38 \\
\hline 2010 & 18.9 & 20.80 & 3049 & 3360 & -0.62 \\
\hline 2015 & 25.6 & 28.20 & 3114 & 3432 & -0.82 \\
\hline 2020 & 29.0 & 32.00 & 3248 & 3579 & -0.89 \\
\hline 2025 & 39.5 & 43.60 & 4412 & 4862 & -0.90 \\
\hline 2030 & 31.2 & 34.30 & 3488 & 3844 & -0.89 \\
\hline
\end{tabular}

Cumulative $\mathrm{CO}_{2}$ reduction $1998-2030=686 \mathrm{Mt}$ (756 million short tons) 
Table 6. Projected Reduction of Pollutants for Refrigerators, RefrigeratorFreezers, and Freezers, Standard Level Three

$\mathrm{SO}_{2}$

\begin{tabular}{|c|c|c|c|c|c|}
\hline Year & \multicolumn{2}{|c|}{$\begin{array}{l}\text { Abated from Power Plant } \\
\text { Generation } \\
\text { kt (10 of short tons) }\end{array}$} & \multicolumn{2}{|c|}{$\begin{array}{l}\text { Tótal Emissions } \\
\text { kt }\left(10^{3} \text { of short tons }\right)\end{array}$} & $\begin{array}{l}\% \text { U.S. } \mathrm{SO}_{2} \text { Power } \\
\text { Plant Emissions }\end{array}$ \\
\hline 1998 & 7.0 & 7.7 & 12362 & 13623 & -0.06 \\
\hline 2000 & 16.4 & 18.1 & 9853 & 10858 & -0.17 \\
\hline 2005 & 38.7 & 42.6 & 8867 & 9772 & -0.44 \\
\hline 2010 & 55.9 & 61.7 & 7956 & 8767 & -0.70 \\
\hline 2015 & 60.8 & 67.1 & 6546 & 7214 & -0.93 \\
\hline 2020 & 55.6 & 61.3 & 5489 & 6048 & -1.01 \\
\hline 2025 & 44.9 & 49.5 & 4412 & 4862 & -1.02 \\
\hline 2030 & 35.5 & 39.1 & 3488 & 3844 & -1.02 \\
\hline
\end{tabular}

Cumulative $\mathrm{SO}_{2}$ reduction, $1998-2030=1465 \mathrm{kt}$ (1615 thousand short ton)

No

\begin{tabular}{|c|c|c|c|c|c|}
\hline Year & & $\begin{array}{l}\text { from Power Plant } \\
\text { Generation } \\
\left(10^{3} \text { of short tons) }\right.\end{array}$ & kt & $\begin{array}{l}\text { otal Emissions } \\
\left(10^{3} \text { of short tons }\right)\end{array}$ & $\begin{array}{l}\% \text { U.S. NO } \mathrm{x}_{x} \text { Power } \\
\text { Plant Emissions }\end{array}$ \\
\hline 1998 & 4.7 & 5.2 & 8356 & 9208 & -0.06 \\
\hline 2000 & 12.2 & 13.5 & 7355 & 8083 & -0.17 \\
\hline 2005 & 31.1 & 34.3 & 7136 & 7864 & -0.44 \\
\hline 2010 & 48.6 & 53.6 & 6914 & 7619 & -0.70 \\
\hline 2015 & 56.4 & 62.2 & 6070 & 6689 & -0.93 \\
\hline 2020 & 55.6 & 61.3 & 5489 & $6048^{\circ}$ & -1.01 \\
\hline 2025 & 49.2 & 54.2 & 4836 & 5330 & -1.02 \\
\hline 2030 & 43.6 & 48.1 & 4289 & 4726 & -1.02 \\
\hline
\end{tabular}

Cumulative $\mathrm{NO}_{\mathrm{x}}$ reduction, $1998-2030=1393 \mathrm{kt}$ ( 1535 thousand short tons)

\begin{tabular}{|c|c|c|c|c|c|}
\hline Year & \multicolumn{2}{c|}{$\begin{array}{c}\text { Abated from Power Plant } \\
\text { Generation }\end{array}$} & \multicolumn{2}{|c|}{$\begin{array}{c}\text { Total Emissions } \\
\text { (10\% of short tons) }\end{array}$} & \multicolumn{2}{|c|}{ kt $\left(10^{3}\right.$ of short tons) } & $\begin{array}{c}\text { \% U.S. CO } \mathrm{CO}_{2} \text { Power } \\
\text { Plant Emissions }\end{array}$ \\
\hline 1998 & 1.5 & 1.7 & 2714 & 2990 & -0.06 \\
2000 & 4.6 & 5.0 & 2744 & 3024 & -0.17 \\
2005 & 12.7 & 14.0 & 2918 & 3216 & -0.44 \\
2010 & 21.4 & 23.6 & 3049 & 3360 & -0.70 \\
2015 & 28.9 & 31.9 & 3114 & 3432 & -0.93 \\
2020 & 32.9 & 36.3 & 3248 & 3579 & -1.01 \\
2025 & 34.2 & 37.7 & 3365 & 3708 & -1.02 \\
2030 & 35.5 & 39.2 & 3491 & 3848 & -1.02 \\
\hline
\end{tabular}

Cumulative $\mathrm{CO}_{2}$ reduction, $1998-2030=778 \mathrm{Mt}(858$ million short tons $)$ 
Table 7. Projected Reduction of Pollutants for Refrigerators, RefrigeratorFreezers, and Freezers, Standard Level Four

$\mathrm{SO}_{2}$

\begin{tabular}{|c|c|c|c|c|c|}
\hline Year & & $\begin{array}{l}\text { from Power Plant } \\
\text { Generation } \\
\text { (10 } 10^{3} \text { of short tons) }\end{array}$ & & $\begin{array}{l}\text { sions } \\
\text { ort tons) }\end{array}$ & $\begin{array}{l}\% \text { U.S. SO }{ }_{2} \text { Power } \\
\text { Plant Emissions }\end{array}$ \\
\hline 1998 & 8.1 & 8.9 & 12362 & 13623 & -0.07 \\
\hline 2000 & 19.1 & $21.1-$ & 9853 & 10858 & -0.19 \\
\hline 2005 & 45.4 & 50.1 & 8867 & 9772 & -0.51 \\
\hline 2010 & 65.6 & 72.3 & 7956 & 8767 & -0.82 \\
\hline 2015 & 71.5 & 78.8 & 6546 & 7214 & -1.09 \\
\hline 2020 & 65.3 & 72.0 & 5489 & 6048 & -1.19 \\
\hline 2025 & 52.7 & 58.1 & 4412 & 4862 & -1.20 \\
\hline 2030 & 41.6 & 45.9 & 3488 & 3844 & -1.19 \\
\hline
\end{tabular}

Cumulative $\mathrm{SO}_{2}$ reduction, $1998-2030=1720 \mathrm{kt}$ (1896 thousand short tons)

\begin{tabular}{|c|c|c|c|c|c|}
\hline Year & $\begin{array}{l}\mathrm{Ab} \\
\mathrm{kt}\end{array}$ & $\begin{array}{l}\text { from Power Plant } \\
\text { Jeneration } \\
\left(10^{3} \text { of short tons }\right)\end{array}$ & & $\begin{array}{l}\text { al Emissions } \\
\left(10^{3} \text { of short tons) }\right.\end{array}$ & $\begin{array}{c}\% \text { U.S. NO } \text { Nower }_{x} \text { Pows } \\
\text { Plant Emissions }\end{array}$ \\
\hline 1998 & 5,5 & 6.0 & 8356 & 9208 & -0.07 \\
\hline 2000 & 14.2 & 15.7 & 7335 & 8083 & -0.19 \\
\hline 2005 & 36.6 & 40.3 & 7136 & 7864 & -0.51 \\
\hline 2010 & 57.0 & 62.8 & 6914 & 7619 & -0.82 \\
\hline 2015 & 66.3 & 73.1 & 6070 & 6689 & -1.09 \\
\hline 2020 & 65.3 & 72.0 & 5489 & 6048 & -1.19 \\
\hline 2025 & 57.8 & 63.7 & 4836 & 5330 & -120 \\
\hline 2030 & 51.2 & 56.4 & 4289 & 4726 & -1.19 \\
\hline
\end{tabular}

Cumulative $\mathrm{NO}_{\mathrm{x}}$ reduction, $1998-2030=1635 \mathrm{kt}$ (1802 thousand short tons)

\begin{tabular}{|c|c|c|c|c|c|}
\hline \multirow[b]{2}{*}{ Year } & \multirow{2}{*}{\multicolumn{2}{|c|}{$\begin{array}{c}\text { Abated from Power Plant } \\
\text { Generation }\end{array}$}} & \multicolumn{2}{|c|}{ Total Emissions } & \multirow{2}{*}{$\begin{array}{l}\% \text { U.S. } \mathrm{CO}_{2} \text { Power } \\
\text { Plant Emissions }\end{array}$} \\
\hline & & & & ( $10^{3}$ of short tons) & \\
\hline 1998 & 1.8 & 2.0 & 2714 & 2990 & -0.07 \\
\hline 2000 & 5.3 & 5.9 & 2744 & 3024 & -0.19 \\
\hline 2005 & 14.9 & 16.5 & 2918 & 3216 & -0.51 \\
\hline 2010 & 25.1 & 27.7 & 3049 & 3360 & -0.82 \\
\hline 2015 & 34.0 & 37.5 & 3114 & 3432 & -1.09 \\
\hline 2020 & 38.6 & 42.6 & 3248 & 3579 & -1.19 \\
\hline 2025 & 40.2 & 44.3 & 3365 & 3708 & -1.20 \\
\hline 2030 & 417 & 46.0 & 3491 & 3848 & -1.19 \\
\hline
\end{tabular}

Cumulative $\mathrm{CO}_{2}$ reduction, $1998-2030=914 \mathrm{Mt}$ (1007 million short tons) 


\subsection{Cumulative Impacts}

The CAAA calls for $\mathrm{SO}_{2}$ emissions reductions in two phases. In the first phase of the planned reductions (beginning December 31, 1995 and carrying through the year 2000), electric utilities will have several options for reducing their $\mathrm{SO}_{2}$ emissions to comply with the allowance constraints imposed by the CAAA. The major options are 1) to decrease use of high emission units and increase the use of their clean units, 2) to switch units using high sulfur coal to low sulfur coal, 3) to retrofit plants emitting at a high rate with emissions-reduction technologies (e.g, scrubbers), 4) to purchase allowances from other utilities that reduce their emissions below their permitted levels, and 5) to purchase power rather than generate it. Most utilities will make use of a combination of these options to minimize the cost of complying with the allowance constraints. Total $\mathrm{SO}_{2}$ emissions by utilities cannot exceed 8.1 Mt ( 8.9 million short tons) after December 31 , 2000.

In the second phase of the planned reductions (beginning December 31,2000), the options available to electric utilities for maintaining the $8.1 \mathrm{Mt}$ cap will broaden with the expected introduction of new, advanced generating technologies. However, during this period utilities will be less able to reduce emissions by changing the way they utilize their plants. Since most plants will be fully utilized, there will be few opportunities for reducing emissions by decreasing the use of a high emission plant or for further fuel switching.

The proposed adoption of the efficiency standard level 1 for this type of appliance would likely not affect the overall quantity of physical emissions of $\mathrm{SO}_{2}$ which, because of $\mathrm{SO}_{2}$ allowance trading, will hover near the ceiling permitted under the CAAA. This is not to say that there would be no $\mathrm{SO}_{2}$ emissions benefit to be derived from the lowered electricity demand expected from the proposed appliance standard. Actual physical emissions would not necessarily be lowered, but the demand for $\mathrm{SO}_{2}$ allowances by electricity generators would be reduced, resulting in lower allowance prices, and lower electric utility compliance costs. In other words, lowered generation is a costless means for a utility to achieve some of the $\mathrm{SO}_{2}$ reduction required by the CAAA. Estimating these effects as they reverberate through $\mathrm{SO}_{2}$ allowance trading, however, is beyond the scope of this analysis. Therefore, emissions reductions by weight are simply estimated and reported, as if the allowance trading market did not exist.

\subsection{Environmental Justice}

Because neither the proposed adoption of Standard Level 1 nor the alternative standards would have adverse impacts on the environment, there would be no disproportionate and adverse impacts on low-income and minority communities pursuant to Executive Order 12898 on Environmental Justice.

\subsection{List of Agencies and Persons Consulted}

None. 


\section{REFERENCES}

1. National Appliance Energy Conservation Act (NAECA), Public Law 100-12, March 17, 1987.

2. U.S. DOE. Energy Information Administration. Effects of the Clean Air Act Amendments on Reducing $\mathrm{SO}_{2} \mathrm{NO}_{x}$ Emissions. Energy Information Administration, SR/NES/90-01, 1990. 
POLLUTANT REUUCTIONS FOR RERRIGERATORS, REFRIGERATOR-FREEZERS AND FRERZERS

Standard Level: Finel Rule

Az097 Fuel Prices

SO2 emissions:

Abated from

Year Power plant

$000 \cdot s$

kt short

$\begin{array}{lll}2005 & 21.95 & 24.20 \\ 2010 & 43.79 & 48.26 \\ 2015 & 62.06 & 68.39 \\ 2020 & 71.66 & 78.96 \\ 2025 & 73.35 & 80.84\end{array}$

$2030 \quad 68.00 \quad 74.93$

cumulative so2 reduction, $1545 \mathrm{kt}=1703$ 000 short tors

NOx emissions:



CO2 emissions:

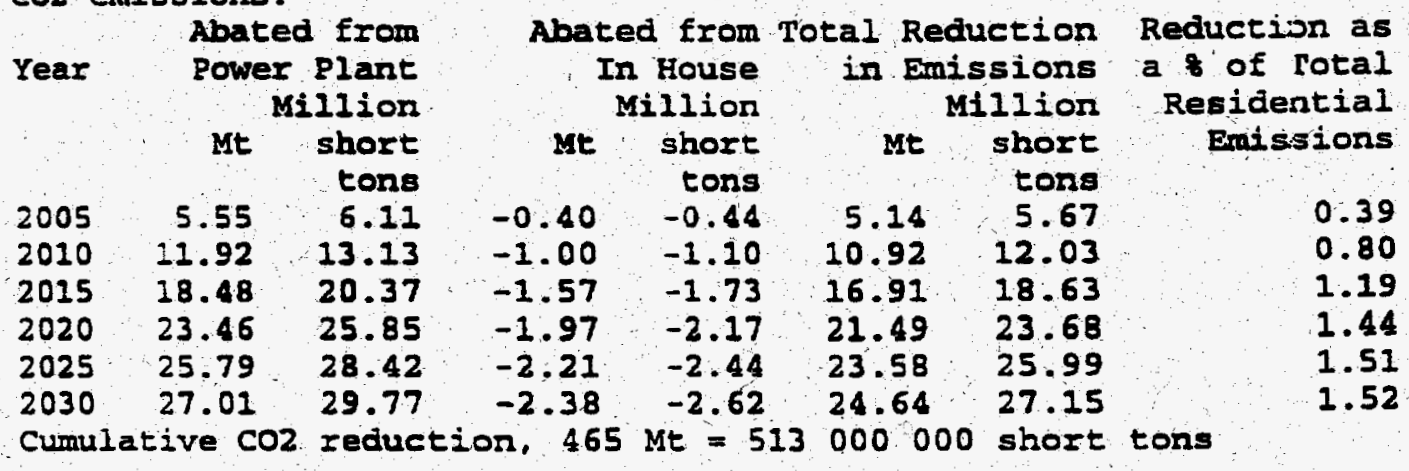

Reductiun as

a of ot lotal

Residential

0.56

1.16

1.70

2.06

2.16

2.15
Bnisisions

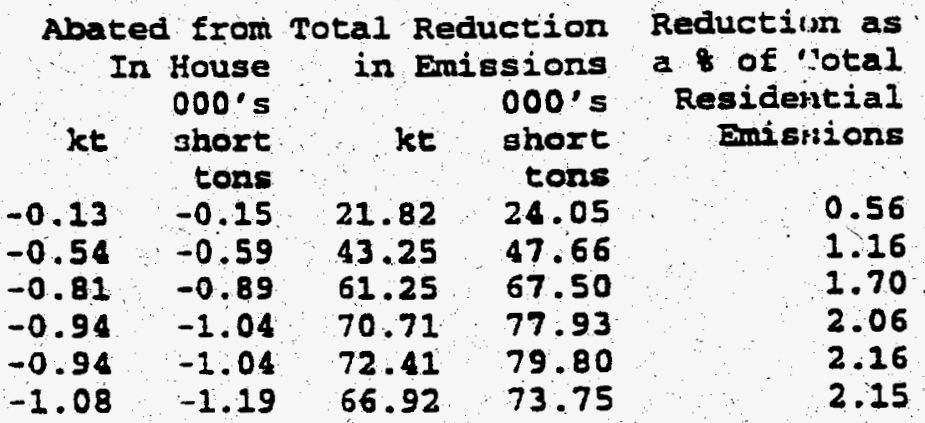

